\title{
CT Guided TTNA and Core Biopsy in Suspected Lung Cancer, Review of Cases in Adam Malik General Hospital, Medan
}

\author{
Hadi Suhendra1 ${ }^{1}$, Fajrinur Syarani ${ }^{1}$, Syamsul Bihar ${ }^{1}$, Putri Chairani Eyanoer ${ }^{2}$ \\ ${ }^{1}$ Department of Pulmonology and Respiratory Medicine, Faculty of Medicine \\ Universitas Sumatera Utara, Medan \\ ${ }^{1}$ Department of Community and Preventive Medicine, Faculty of Medicine \\ Universitas Sumatera Utara, Medan
}

\begin{abstract}
Corresponding Author:
Hadi Suhendra| Departement of Pulmonology and Respiratory Medicine, Faculty of Medicine Universitas Sumatera Utara, Medan | hadhendra@gmail.com
\end{abstract}

Submitted: July $6^{\text {th }}, 2021$

Accepted: July $30^{\text {th }}, 2021$

Published: October $15^{\text {th }}, 2021$

Respir Sci. 2021; 2(1): 18-27

https://doi.org/10.36497/respirsci.v1i3.27

\begin{abstract}
Backgrounds: The cytological and histopathological findings establish the type of lung cancer cells as the definitive diagnosis of lung cancer. This study aimed to determine the characteristics of lung cancer patients in terms of age, mean age, gender, staging, and the proportion of lung cancer cells by cytologic examination of Transthoracic Needle Aspiration (TTNA) and histopathologic evaluation from CT-guided core biopsy.

Method: This is a descriptive study involving 42 subjects diagnosed with lung cancer at $\mathrm{H}$. Adam Malik Hospital Medan in 2016-2020 that met the inclusion criteria through consecutive sampling. Data was analysed using descriptive statistics for categorical variables.

Results: Of 42 study subjects, the 60-71-year age group had the highest percentage of lung cancer $(42.9 \%)$. Male $(71.4 \%)$ was higher than female, the most common lung cancer staging was IVA $(57.1 \%)$, and adenocarcinoma was found to be the most frequent type of lung cancer in both cytology (33.3\%) and histopathology (31.0\%).

Conclusion: We concluded that core biopsy is superior in diagnosing lung cancer compared to TTNA.

Keywords: core biopsy, cytology, histopathology, TTNA
\end{abstract}

\section{INTRODUCTION}

Lung cancer, in its broadest meaning, refers to all cancers of the lungs, including malignancies that originate in the lungs and malignancies that originate outside the lungs. Lung cancer refers to primary lung cancer, which is defined as malignant tumors that arise from the bronchial epithelium, also known as bronchial carcinoma (bronchogenic carcinoma). Lung cancer is especially lethal because it has the worst prognosis, with high mortality and morbidity, a low survival rate, and difficulties in early detection and screening. ${ }^{1,2}$

Lung cancer was rare in the early 20th century, but it is gradually becoming more common. According to the 2012 GLOBOCAN report, there were 1.8 million new lung cancer cases globally, $12.9 \%$ of the total estimated cancer incidence in 2012. The global geographic distribution of lung cancer shows marked regional 
variation. Males have the highest incidence of lung cancer in Central and Eastern Europe (53.5 per 100,000) and East Asia (50.4 per 100,000$)$. Central and western Africa show low incidence rates (2.0 and 1.7 per 100,000, respectively). Females tend to have a lower incidence rate and a slightly different geographic distribution, particularly if they have a history of smoking. ${ }^{3,4}$

Indonesia ranks third after China and India, with the incidence of cancer reaching 25,322 cases with a death rate of 22,522 cases. Lung cancer was estimated to affect $1,098,700$ males and 491,200 females worldwide in 2012 , accounting for $24 \%$ and $14 \%$ of all cancer deaths in males and females, respectively. Smoking is strongly linked to lung cancer incidence, with longterm smokers having a $10 \%$ risk, and those without a smoking history having a $10-15 \%$ risk due to environmental and genetic factors. ${ }^{5-7}$

Several studies have shown that the characteristics and clinical features of lung cancer patients have not changed. The data show more cases in males aged $>40$ years and smokers. The most common histologic finding (85\%) is Non-Small Cell Lung Carcinoma (NSCLC); the results show that the 5-year survival rate of early-stage lung cancer was around $14 \%$, and when it is in an advanced stage, only about $10 \%$ survived an average of 9-14 months. ${ }^{1,8}$

Histopathological analysis of lesions in the lung is mandatory if lung cancer is suspected to determine the optimal diagnostic setting. The specimen material acquired should be adequate for a definitive histopathological diagnosis and should be superior to cytology.

In some cases, particularly adenocarcinoma, molecular analysis is essential. Two methods to obtain sufficient biopsy samples are flexible bronchoscopy and CT-guided lung biopsy. Flexible bronchoscopy is the best method for locating proximal tumors; whereas, CTguided lung biopsy is more accurate for locating peripheral tumors. CT-guided lung biopsy, if conducted safely, has a sensitivity of $90 \%$ for the diagnosis of lung cancer. Complications are less common, particularly hemoptysis and pneumothorax, which require the insertion of a chest tube. ${ }^{9}$

This study aimed to determine the profile of the histopathological examination of core biopsy and CT-guided TTNA in patients diagnosed with lung cancer.

\section{METHOD}

This is a descriptive study involving 42 subjects diagnosed with lung cancer at H. Adam Malik Hospital Medan in 20162020 that met the inclusion criteria through consecutive sampling. For categorical variables, the data in this study were examined descriptively. The outcome is presented in the form of frequency and percentage (proportion). This study has been approved by the Ethical Research Committee of the Faculty of Medicine at Universitas Sumatera Utara.

\section{RESULTS}

We collected data for four months (April 2020 to August 2020). This study 
involved 42 samples taken from the population according to the inclusion and exclusion criteria. The majority of the patients in this study were male $(71.4 \%)$. The 60-71-year age group had the highest percentage of lung cancer (42.9\%). A detailed description can be seen in Table 1.

Table 1 . The characteristics of subjects $(\mathrm{N}=42)$

\begin{tabular}{|c|c|c|}
\hline Variables & $\mathbf{n}$ & $\%$ \\
\hline \multicolumn{3}{|l|}{ Gender } \\
\hline Male & 30 & 71,4 \\
\hline Female & 12 & 28,6 \\
\hline \multicolumn{3}{|l|}{ Age } \\
\hline $18-30$ years old & 2 & 4,8 \\
\hline $31-40$ years old & 3 & 7,1 \\
\hline $41-50$ years old & 2 & 4,8 \\
\hline $51-60$ years old & 10 & 23,8 \\
\hline $61-70$ years old & 18 & 42,5 \\
\hline $71-80$ years old & 5 & 11,9 \\
\hline $81-90$ years old & 2 & 4,8 \\
\hline Average Age & 59 years old & \\
\hline
\end{tabular}

Lung cancer staging in this study sample used the TNM system classification according to the International Staging System for Lung Cancer version 8 in 2017 and the most common lung cancer staging was IVA (57.1\%) as seen in Table 2.

Table 2. Lung cancer staging $(\mathrm{N}=42)$

\begin{tabular}{lcc}
\hline \multicolumn{1}{c}{ Lung cancer staging } & $\mathbf{n}$ & $\mathbf{\%}$ \\
\hline IA & 1 & 2,4 \\
IIB & 5 & 11,9 \\
IIIA & 9 & 21,4 \\
IIIB & 2 & 4,8 \\
IVA & 24 & 57,1 \\
IVB & 1 & 2,4 \\
\hline
\end{tabular}

The results of histopathological analysis of the core biopsy in this study consisted of Non-Small Cell Lung Cancer (NSCLC) and Small Cell Lung Cancer (SCLC). In this study, adenocarcinoma was found to be the most frequent type of lung cancer $(31.0 \%)$ as seen in Table 3.
Table 3. Core biopsy histopathology $(\mathrm{N}=42)$

\begin{tabular}{lcc}
\hline \multicolumn{1}{c}{ Core biopsy histopathology } & $\mathbf{n}$ & $\mathbf{\%}$ \\
\hline Adenocarcinoma & 13 & 31.0 \\
Poorly Differentiated Adenocarcinoma & 3 & 7.1 \\
Well Differentiated Adenocarcinoma & 1 & 2.4 \\
Adenosquamous cell carcinoma & 1 & 2.4 \\
Squamous cell carcinoma & 11 & 26.2 \\
Not representative & 8 & 19.0 \\
Atypical tissue & 2 & 4.8 \\
Melanoma metastases & 1 & 2.4 \\
Benign lesion & 1 & 2.4 \\
Yolk sac tumour & 1 & 2.4 \\
\hline
\end{tabular}

Cytological diagnosis of lung cancer is based on the 2015 World Health Organization (WHO) classification system and the International Association for the Study of Lung Cancer (IASLC). Pathologists analyzed the cytologic findings of the CTguided TTNA using the following classifications was (C1) inadequate, (C2) benign smear/inflammatory smear, (C3) atypical, (C4) suspected malignant, (C5) malignant smear.

Four samples were considered inadequate, five samples were benign smears, four samples were hemorrhagic smears, two samples were atypical, one was suspected malignant, and 26 samples were malignant (Table 4).

Table 4. Transthoracic Needle Aspiration Cytology $(\mathrm{N}=42)$

\begin{tabular}{lcc}
\hline \multicolumn{1}{c}{$\begin{array}{c}\text { Transthoracic Needle } \\
\text { Aspiration Cytology }\end{array}$} & $\mathbf{n}$ & $\mathbf{\%}$ \\
\hline C1 Inadequate & 4 & 9.5 \\
C2 & 5 & 11.9 \\
$\quad$ Benign Smear & 4 & 9.5 \\
$\quad$ Hemorrhagic smear & 2 & 4.8 \\
C3 Atypical & 1 & 2.4 \\
C4 Suspected malignant & & \\
C5 & 3 & 7.1 \\
Malignant smear & 14 & 33.3 \\
Adenocarcinoma & 9 & $21, .4$ \\
$\quad$ Squamous cell carcinoma & &
\end{tabular}




\section{DISCUSSION}

In this study, we found that in establishing lung cancer diagnosis using a core biopsy, more malignant cells were found in the core biopsy (69.1\%) than in the TTNA procedure (62.2\%). It could be because the TTNA needle size is smaller than the Core biopsy, thus the sample adequacy of the Core biopsy is better than TTNA. The experience of the operator who performed the TTNA and core biopsy, the presence of a pathologist at the time of the TTNA and core biopsy were done, and the type of devices used during the procedure were also thought to be the reasons. ${ }^{10}$

In TTNA, one factor affects the diagnostic results of lung cancer adalah the interpretation of the anatomic pathologist who concludes of the obtained aspirate. Currently, there is no standard category in the cytopathological assessment of lung cancer. Other factors that affect the adequacy of samples on TTNA and Core Biopsy are the size and location of the nodules found on CT scans and the number of needle punctures in sampling. In contrast, the depth of the needle puncture and the patient's position does not affect the diagnostic value. ${ }^{11,12}$

Core biopsy is preferable to TTNA because it minimizes the likelihood of diagnostic failure and to obtain sufficient tissue samples for molecular histopathological analysis. TTNA, on the other hand, has advantages because it is less expensive, Rapid On-site Evaluation (ROSE) can be directly performed, and pathologists can directly assess the adequacy of samples and types of cancer cells so that an accurate diagnosis is established. ${ }^{13,14}$

Although Core Biopsy produces a higher diagnostic value than TTNA, Core Biopsy has more significant complications than TTNA. The most common complications found are pneumothorax and bleeding. It is associated with a larger needle size in Core Biopsy compared to TTNA. It is the reason that a core biopsy is not always necessary, simply using TTNA and accompanied by a pathologist will produce a better diagnostic value. ${ }^{15}$

There is a wide variation in reporting the diagnostic accuracy of TTNA wherein the sensitivity, specificity and accuracy of TTNA are 82 to $99 \%, 86$ to $100 \%$ and 64 to $97 \%$, respectively. Core Biopsy shows a slightly higher sensitivity, specificity, and overall accuracy, with $89 \%, 97 \%$ and $93 \%$, respectively. This study recommends using needle sizes 18 and 20 and the coaxial technique to improve diagnostic results resulting in a diagnostic accuracy value of $74-95 \%$ for the diagnosis of malignancy. Schneider et al. discovered that Core Biopsy had statistically better sample size adequacy for molecular testing than TTNA (67\% vs 46\%; $P=0.007)^{16}$

The study that measured the diagnostic accuracy of CT Scan-guided Core biopsy of small lung nodules was $96.1 \%$, with $100 \%$ technical success. This study indicates that CT-guided core biopsy is an effective method for diagnosing small lung nodules. Previous studies showing TTNA to diagnose small lung nodules $(20 \mathrm{~mm})$ showed that the diagnostic 
accuracy was only $64.6 \%$ to $77.2 \%$. The size of the nodule affects the diagnostic accuracy of TTNA and core biopsies. The diagnostic failure of TTNA is influenced by the size of the lung nodules. ${ }^{17}$

Univariate analysis showed that the predictors of diagnostic success of Core Biopsy were tumour size $>3 \mathrm{~cm}$, use of coaxial needle and $2.5 \mathrm{~mm}$ thorax CT Scan slice thickness, use of additional imaging and Ground Glass Opacity (GGO) images and obstructive pneumonitis reduced the diagnostic value of Core Biopsy. The diagnostic accuracy of TTNA (82\%) and Core Biopsy (92\%), Core Biopsy is better in the adequacy of tissue samples in assessing anatomical pathologists to produce a correct diagnosis. The risk of pneumothorax and bleeding is greater in Core Biopsy due to a larger needle. ${ }^{18,19}$

This study included 42 samples. From all the samples, the majority gender is male, 30 patients (71.4\%). Some previous studies analyzing TTNA and core biopsy with ct scan guidance showed more males $(67.8 \%)$ and females (32.2\%). Another study conducted in Japan also found that males $(60 \%)$ were more common than females (40\%). ${ }^{12,20}$

A study conducted at Chang Gung Hospital, Taiwan, found that there were 20 males and 23 females in group A (lesion $\leq 15 \mathrm{~mm}$ ) and 86 males and 69 females in group B (lesion >15 mm). A study conducted at the Kosin University Hospital, Busan, North Korea, showed more male (196 patients) than female (104 patients). Based on 2018 Translational Lung Cancer Research (TLCR) data, new estimates of lung cancer in the United States in 2018 were 121,680 for men and 112,350 for women, for a total of 234,030 , equivalent to 641 lung cancers diagnosed per day. ${ }^{10,21,22}$

In a study conducted at the Department of Pulmonology and Respiratory Medicine, Faculty of Medicine, Universitas Sumatera Utara in 2019, regarding the diagnosis of lung cancer using a CT-guided core biopsy, found that there were $78 \%$ more males and $10 \%$ females, this shows no difference from previous studies. In a study conducted at the Department of Pulmonology and Respiratory Medicine, Faculty of Medicine, Universitas Sumatera Utara in 2016, regarding the diagnostic accuracy of Ultrasound-guided TTNA in lung cancer, it was found that the males were mainly around $76.1 \%$ and followed by the females $23.9 \%$, this shows not much different from previous studies. ${ }^{23,24}$

Lung cancer is the second most common cancer diagnosis by gender, after prostate cancer in men and breast cancer in women. In 2018, lung cancer accounted for $14 \%$ of new cancers in men and $13 \%$ of new cancers in women in the US. ${ }^{22}$

According to hospital-based cancer registration data at the Dharmais Cancer Hospital, Jakarta, in 2003-2007, lung cancer was the most common malignancy in males $(5.92 / 100,000)$, while in females, it was fourth $(5.52 / 100,000)$. Data at Persahabatan Hospital Jakarta, in 20042006 , showed that about $83.4 \%$ of lung cancer patients were male and $43.4 \%$ female patients, which was associated with 
a history of smoking. The number of lung cancer patients at $\mathrm{H}$. Adam Malik Hospital in Medan increases; based on Melindawati's research (2008), the gender are primarily male, around $86.1 \%$, and the aged over 60 years are around $40.8 \%{ }^{8}$

Several studies have shown that the characteristics and clinical features of lung cancer patients have not changed. The data show more cases in men aged over 40 years and smokers. In this study, the average age of the entire sample was 59 years. These results are not much different from previous similar studies. A previous study conducted at the Suleyman Demirel University, Isparta, Turkey, found a mean age of 64 years. A study conducted at the University of Maastricht, the Netherlands, from 35 samples found that the average age was 65 years, indicating that age is one of the risk factors for lung cancer. ${ }^{1,25,26}$

One of the factors influencing lung cancer prognosis is the stage of the disease. According to various reports, the majority of lung cancer patients are determined based on the disease's advanced stage. The most common staging in this study was stage IVA, which accounted for $57.1 \%$ of all staging. In Indonesia, lung cancer is typically diagnosed when the disease has progressed to an advanced stage. Early identification of lung cancer based on moderate symptoms occurs in people in stages II and III. A study on women who had never smoked at the $\mathrm{H}$. Adam Malik General Hospital Medan found an elevated risk of lung cancer in women who had never smoked. Stage IV lung cancer was the most common. ${ }^{1,27,28}$

A study conducted at Dharmais Cancer Hospital Jakarta from 2008 to 2012 discovered that stage IV lung cancer was the most common, accounting for up to $26.2 \%$ of all cases. Because it frequently occurs without symptoms in the early stages, lung cancer is frequently discovered at an advanced level. The majority of lung cancer deaths are caused by metastases to distant organs. Lung cancer frequently spreads to other organs such as the brain, liver, bones, and adrenal glands. ${ }^{29,30}$

The histopathological analysis results from the core biopsy in this study used the Histopathological Classification of lung cancer, specifically Non-Small Cell Lung Cancer (NSCLC), adenocarcinoma, squamous cell carcinoma, large cell carcinoma, and Small Cell Lung Cancer (SCLC), small cell carcinoma, and other types of cancer cells. In this study, the most common cell type was adenocarcinoma in 13 patients $(31.0 \%)$.

Most of the literature shows that adenocarcinoma cells are the most common lung cancer malignancies. A study conducted at the Department of Pulmonology and Respiratory Medicine, Faculty of Medicine, Universitas Sumatera Utara in 2019, about the diagnosis of lung cancer using a core biopsy with the CT scan guidance, found that Squamous Cell Carcinoma cells were more in about ten patients (25\%) followed by adenocarcinoma cells 11 patients (23\%), this looks slightly different from the 
previous study. The results of a similar study at Sichuan University, Chengdu, China, showed that from 338 samples with histopathological results, namely 213 (63\%), adenocarcinoma 7 (2.1\%), squamous cell carcinoma 35 (10.4\%), large neuroendocrine cells 6 (1.8\%). ), small cell carcinoma 20 (5.9\%), Lymphoma 4 (1.2\%), tumor metastases 39 $(1.5 \%)$, undifferentiated lung carcinoma $14(4.1 \%){ }^{23,31}$

This study shows that the most common type of lung cancer is adenocarcinoma. A study conducted at Adana Numune Hospital, Turkey, with a total of 65 samples, found histopathological results, specifically with adenocarcinoma malignancy cells, 11 (16.9\%), epidermoid carcinoma 8 (12.3), small cell carcinoma 4 (6.2), lymphoma 2 (3.1\%), pleomorphic carcinoma $1(1.5 \%)$, metastatic $7(10.8 \%)$, undifferentiated lung carcinoma 14 (21.6\%), benign lesion $12(18.4 \%)$, Not representative 6 (9.2\%). Another similar study conducted at Nanjing University, China, found that the most malignant cells were adenocarcinoma with 158 (50.9\%) followed by squamous cell carcinoma with $34(11 \%)$. The results in this study were also the most common type of lung cancer, adenocarcinoma, than other types of lung cancer cells. ${ }^{12,32}$

Cytological diagnosis of lung cancer using based on the 2015 World Health Organization (WHO) classification system and the International Association for the Study of Lung Cancer (IASLC). Anatomical Pathologists analyze the cytology of the TTNA procedure with CT scan guidance using the following classifications: (C1) inadequate,

benign smear/inflammatory smear, (C3) atypical, (C4) suspected malignant, (C5) malignant smear. In this study found $\mathrm{C} 1, \mathrm{C} 2, \mathrm{C} 3, \mathrm{C} 4$, C5 4 (9.5\%), 9 (21.4\%), 2 (4.8\%), 1 $(2.4 \%), 26(61.8 \%)$ respectively.

This study found that the most common malignant cells were adenocarcinoma in 14 patients (33.3\%) and squamous cell carcinoma in 9 patients (21.4\%). The literature also indicates that the most common type is adenocarcinoma. A study conducted at the Department of Pulmonology and Respiratory Medicine, Faculty of Medicine, Universitas Sumatera Utara in 2016, about the diagnostic accuracy of TTNA with chest ultrasound guidance in lung cancer, found 17 patients $(37 \%)$ of adenocarcinoma cell types. Followed by Squamous Cell Carcinoma in five patients (10\%), this does not appear to be much different from previous studies. ${ }^{24}$

A similar study conducted at the Massachusetts Hospital, Boston, United States, found that there were 76 patients (88.3\%) adenocarcinoma cells (88.3\%), two patients $(2.3 \%)$ poorly differentiated adenocarcinoma, one patient (1.16 \%) pancreatic cancer metastases, benign lesion one patient $(2.3 \%)$, inadequate 11 patients (12.7\%). A similar study conducted at the University of Texas, United States, also found that the most adenocarcinoma cells were found in 40 patients $(18.6 \%)$, squamous cell carcinomas 25 patients $(11.6 \%)$, carcinoma metastases 26 patients (12\%), 
melanoma metastases two patients $(0.93 \%)$, benign lesions were 70 patients $(32.5 \%)$, atypical was 13 patients $(6 \%) .{ }^{15,33}$

Adenocarcinoma is the most common cell type in peripheral lesions with central fibrosis and pleural thickening, found in most smokers and nonsmokers. Adenocarcinoma is the most common type of lung cancer; about $40 \%$ of lung cancers and $60 \%$ of lung cancers and $60 \%$ of lung cancers are non-small cell carcinomas, and more than $70 \%$ of cases of routine surgery. The second most common type of cancer cells found in squamous cell carcinoma, usually found in central lesions found in smokers up to $90 \%$ with significant growth in the intraluminal part of the bronchi, causing atelectasis or obstructive pneumonia. ${ }^{34,35}$

The drawback of this study is that it was conducted retrospectively, which means that misinformation (bias) could have been obtained. The final diagnosis was based primarily on the pathologists' experience, which yielded disparate outcomes. Because the data from the sample was insufficient, there were limitations in the research variables in this study.

\section{CONCLUSION}

On the study subjects 42 patients, there are results in the form of the highest percentage of age $60-71$ years (42.9\%), the average age is 59 years, the most gender is male $(71.4 \%)$, the most lung cancer staging is IV A (57.1\%), the most common lung cancer cell types were adenocarcinoma in cytology (33.3\%) and histopathology (31,0\%). We concluded that Core Biopsy is more effective than TTNA in diagnosing lung cancer.

\section{REFERENCES}

1. Jusuf A, Wibawanto A, Icksan AG, Syahruddin E, Juniarti;, Endardjo S. Kanker Paru. Jakarta: Penerbit Universitas Indonesia (UI Press); 2018.

2. Rasmin M, Anwar J, Amin M, et al. Buku Ajar Pulmonologi Dan Kedokteran Respirasi. 1st ed. Jakarta: Penerbit Universitas Indonesia (UI Press); 2018.

3. Dubey AK, Gupta U, Jain S. Epidemiology of lung cancer and approaches for its prediction: a systematic review and analysis. Chin J Cancer. 2016;35(1):71.

4. Mao Y, Yang D, He J, Krasna MJ. Epidemiology of Lung Cancer. Surg Oncol Clin N Am. 2016;25(3):439-445.

5. Soeroso $N$, Luhur $S$, Hasibuan $P$, Tarigan SP, Bihar S. Kanker Paru Diagnosis Dan Penatalaksanaan. 1st ed. (Soeroso N, Luhur S, Hasibuan P, Tarigan SP, Bihar S, eds.). Medan: USU Press; 2017.

6. Islami F, Torre LA, Jemal A. Global trends of lung cancer mortality and smoking prevalence. Transl Lung Cancer Res. 2015;4(4):327-338.

7. Murray JF, Nadel JA. Murray \& Nadel's Text Book of Respiratory Medicine. 6th ed. Philadelphia: Elsevier; 2016. 
8. Hasibuan P, Soeroso NN. Buku Ajar Respirasi. In: Buku Ajar Respirasi. 1st ed. Medan: USU Press; 2017:397-429.

9. De Margerie-Mellon C, De Bazelaire C, De Kerviler E. Image-guided biopsy in primary lung cancer: Why, when and how. Diagn Interv Imaging. 2016;97(10):965-972.

10. Huang M De, Weng $H H$, Hsu SL, et al. Accuracy and complications of CTguided pulmonary core biopsy in small nodules: A single-center experience. Cancer Imaging. 2019;19(1):1-10.

11. Barta JA, Henschke CI, Flores RM, Yip R, Yankelevitz DF, Powell CA. Lung Cancer Diagnosis by Fine Needle Aspiration Is Associated With Reduction in Resection of Nonmalignant Lung Nodules. Ann Thorac Surg. 2017;103(6):1795-1801.

12. Yang W, Sun W, Li Q, et al. Diagnostic accuracy of CT-guided transthoracic needle biopsy for solitary pulmonary nodules. PLoS One. 2015;10(6):1-9.

13. Lee $K H$, Lim $K Y$, Suh $Y$, et al. Diagnostic accuracy of percutaneous transthoracic needle lung biopsies: A multicenter study. Korean J Radiol. 2019;20(8):1300-1310.

14. Maxwell AWP, Klein JS, Dantey K, Mount SL, Butnor KJ, Leiman G. CTguided transthoracic needle aspiration biopsy of subsolid lung lesions. J Vasc Interv Radiol. 2014;25(3):340-346.e1.

15. Kiranantawat N, McDermott $S$, Petranovic $M$, et al. Determining malignancy in CT guided fine needle aspirate biopsy of subsolid lung nodules: Is core biopsy necessary? Eur
J Radiol Open. 2019;6:175-181.

16. Anzidei $M$, Porfiri $A$, Andrani $F$, et al. Imaging-guided chest biopsies: techniques and clinical results. Insights Imaging. 2017;8(4):419-428.

17. Li GC, Fu YF, Cao W, Shi YB, Wang T. Computed tomography-guided percutaneous cutting needle biopsy for small ( $20 \mathrm{~mm}$ ) lung nodules. Med (United States). 2017;96(46).

18. Lin $\mathrm{CY}$, Chang $\mathrm{CC}$, $\mathrm{Chu} \mathrm{CY}$, et al. Computed Tomography-Guided Transthoracic Needle Biopsy: Predictors for Diagnostic Failure and Tissue Adequacy for Molecular Testing. Front Med. 2021;8(650381):1-14.

19. Ocak S, Duplaquet F, Jamart J, et al. Diagnostic Accuracy and Safety of CTGuided Percutaneous Transthoracic Needle Biopsies: 14-Gauge versus 22Gauge Needles. J Vasc Interv Radiol. 2016;27(5):674-681.

20. Takeshita J, Masago K, Kato R, et al. CT-guided fine-needle aspiration and core needle biopsies of pulmonary lesions: A single-center experience with 750 biopsies in Japan. $A m J$ Roentgenol. 2015;204(1):29-34.

21. Yun S, Kang H, Park S, Kim BS, Park JG, Jung MJ. Diagnostic accuracy and complications of CT-guided core needle lung biopsy of solid and partsolid lesions. $\mathrm{Br} \quad J \quad$ Radiol. 2018;91(1088).

22. de Groot PM, Wu CC, Carter BW, Munden RF. The epidemiology of lung cancer. Transl Lung Cancer Res. 2018;7(3):220-233. 
23. Putra KA, Soeroso, Novisari Noni Taufik $\mathrm{H}$. The Role of Percutaneous Transthoracic Core Needle Biopsy on Diagnostic of Central and Peripheral Lung Nodule/Mass using Chest CT Scan and Chest Ultrasound Guidance. In: Proceedings of the 2nd International Conference on Tropical Medicine and Infectious Disease. Medan; 2019:12-14.

24. Saragih S, Soeroso NN, Syarani F, Zalukhu F, Lubis ND. Akurasi Diagnostik Transthoracic Needle Aspiration dengan Tuntunan Ultrasonografi Toraks pada Kanker Paru Diagnostic Accuracy of Ultrasonography Guided Transthoracic Needle Aspiration for Diagnosing Lung Cancer. J Respir Indo. 2016;36(4):237-243.

25. Aktaş AR, Gözlek E, Yılmaz Ö, et al. CT-guided transthoracic biopsy: Histopathologic results and complication rates. Diagnostic Interv Radiol. 2015;21(1):67-70.

26. Pilleron S, Sarfati D, Janssen-Heijnen $M$, et al. Global cancer incidence in older adults, 2012 and 2035: A population-based study. Int J Cancer. 2019;144(1):49-58.

27. Syahruddin E. Pedoman Penstagingan Dan Pengevaluasian Hasil Terapi Di Indonesia. 1st ed. Jakarta: Perhimpunan Dokter Paru Indonesia; 2019.

28. Soeroso NN, Ananda FR. Lung Cancer among Never-Smoker Women: An Epidemiological Data in North Sumatera, Indonesia. Int $J$ Respir
Med. 2019:1-9.

29. Ramadhaniah F, Khairina $D$, Sinulingga DT, Suzanna E, Mulawarman A. Gambaran Pasien Kanker Paru di Rumah Sakit Kanker Dharmais (RSKD) Tahun 2008-2012. J Respirasiologi Indones. 2019;39(1):31-36.

30. Febriani A, Furqon A. Metastasis Kanker Paru. J Respirasi. 2020;4(3):94.

31. Tian $P$, Wang $Y$, Li L, Zhou Y, Luo W, Li W. CT-guided transthoracic core needle biopsy for small pulmonary lesions: Diagnostic performance and adequacy for molecular testing. $J$ Thorac Dis. 2017;9(2):333-343.

32. Görgülü FF, Öksüzler FY, Arslan SA, Arslan M, Özsoy İE, Görgülü $O$. Computed tomography-guided transthoracic biopsy: Factors influencing diagnostic and complication rates. J Int Med Res. 2017;45(2):808-815.

33. Jing Liu LL. CT-Guided Core Needle Biopsy of Peripheral Lung Lesions with Onsite Adequate Evaluation: Review of 215 Cases. J Cytol Histol. 2014;s4.

34. Zheng M. Classification and Pathology of Lung Cancer. Surg Oncol Clin N Am. 2016;25(3):447-468.

35. Ryan C, Burke L. Pathology of lung tumours. Surg (United Kingdom). 2017;35(5):234-242. 